\title{
School and the Cultural-Heritage Environment: Pedagogical, Creative and Artistic Aspects
}

\section{Hicela IvoN ${ }^{* 1}$ AND Dubravka KuščEvić ${ }^{2}$}

$\approx$ The present paper explores the idea that learning, both in and out of school, is a cultural act, and that school and its cultural-heritage environment stamp their own characteristics on pupils. This implies that pupils gradually, with the help of teachers and other relevant adults from their close social environment, develop and adjust their behaviour and lifestyle to their cultural and civilisational milieu. An integrative approach to learning and teaching, through the concept of "learning-centred teaching", can be instrumental in this regard (Terhart, 2001). This approach aims at linking cognitive, social and moral teachings. According to this teaching concept, pupils learn to appreciate the value of their cultural-heritage environment by living and reliving its experience, while freely and reflexively interpreting and becoming active participants in the culture of those who "learn about life by living" (Terhart, 2001). The relationship between school and its cultural-heritage environment is discussed from a creative and artistic perspective in the second part of the paper. By visually stimulating artistic expression when learning about the culturalheritage and natural environment of school, and through the concept of "action-centred learning", we explain how pupils can be motivated to learn and display creative-artistic expression, and how they can be actively involved in their communities (participating in organising art exhibitions in their neighbourhood, working in museum workshops, etc.). Pupils' art projects, inspired by the historical, cultural and natural heritage of their environment, confirm that such projects are an effective way of encouraging pupils' identity development and sensitivity towards the arts. They teach pupils about the importance of preserving cultural heritage, which is one of the basic principles in the upbringing of future participants and creators of new cultural values. Children's artistic works illustrate examples of good school practice.

Keywords: Cultural-heritage environment; School; Project methods; Pupils' artistic creativity

$1 \quad{ }^{\star}$ Corresponding Author. Faculty of Philosophy, University of Split, Croatia hicela@ffst.hr

2 Faculty of Philosophy, University of Split, Croatia kuscevic@ffst.hr 


\section{Šola in kulturna dediščina okolja: pedagoški, ustvarjalni in umetniški vidik}

Hicela IVON* AND Dubravka KuščEvić

$\propto$ Prispevek utemeljuje prepričanje, da je vsako učenje v šoli in zunaj nje hkrati tudi kulturno ravnanje ter da šola in kulturna dediščina okolja s svojimi značilnostmi zaznamujeta učence. To pomeni, da učenci ob pomoči učiteljev in drugih vplivnih odraslih oseb iz ožjega socialnega okolja razvijejo ter prilagodijo lastno vedenje in življenjski slog skupnemu kulturnemu in civilizacijskemu okolju. Predstavljen je pristop k učenju in poučevanju, ki ga je razvil Terhart (2001) in ga poimenoval koncept akcijskega učenja. Pristop povezuje kognitivno, socialno in moralno poučevanje. Ob uporabi tega pristopa se učenci (na)učijo spoštovati vrednost kulturne dediščine okolja s pomočjo vživljanja in podoživljanja izkušenj. Pri tem svobodno in reflektirano interpretirajo kulturo ter se vanjo aktivno vključujejo prek »izkustvenega učenja« (Terhart, 2001). V drugem delu prispevka je predstavljen odnos med šolo in kulturno dediščino s kreativne in $\mathrm{z}$ umetniške perspektive. Pojasnjeno je, kako lahko s pomočjo vizualnega spodbujanja umetniškega izražanja pri učenju o kulturni dediščini in naravnem okolju šole $s$ pomočjo koncepta akcijskega učenja motiviramo učence za učenje in kreativno umetniško izražanje ter njihovo aktivno udeleženost v lastni skupnosti (s sodelovanjem pri organizaciji umetniških razstav v njihovi soseščini, z delom $\mathrm{v}$ muzejskih delavnicah itn.). Umetniški projekti učencev, ki so izšli iz zgodovinske, kulturne in iz naravne dediščine njihovega okolja, potrjujejo, da so taki projekti učinkovit način spodbujanja razvoja identitete in občutka za umetnost. Učenci se naučijo tudi pomena ohranjanja kulturne dediščine, kar je eno izmed osnovnih načel pri vzgoji prihodnjih udeležencev in soustvarjalcev novih kulturnih vrednot. Pri tem nastala umetniška dela otrok ponazarjajo primere dobre šolske prakse.

Ključne besede: kulturna dediščina okolja; šola; projektne metode; umetniška ustvarjalnost učencev 


\section{Introduction}

When talking about culture and education, it is impossible to ignore the connection between these two concepts. On the one hand, there is culture, with symbolism and an endless range of meanings and content; on the other hand, there is the human being capable of understanding culture, capable of transferring its values in creating new cultures. Social action and social communication are the areas where this cognitive clash of subjects with reality takes place, in which the individual forms his/her knowledge in creating his/her own image of the world, through which he/she realises utterly new and different connections to the world. Thus, it is possible to define culture as a "network or a system of accumulated knowledge, customs, values, beliefs and behaviour patterns with which to solve the fundamental issue - our own survival" (Ogbu, 1989, p. 5).

In the 1990s, Bruner (1990), Shweder (1991) and Wertsch (1991) wrote interesting papers on the tradition of cultural psychology, emphasising the fact that culture is entirely man made, and that it shapes and allows the functioning of the human mind. Their view was that learning and thinking always takes place in specific cultural contexts. "Culture shapes the mind of an individual. Its individual expression is achieved through the creation of meaning, through the attribution of meaning to things in different contexts and situations" (Bruner, 2000, pp. 9-10).

Bruner's idea stems from the evolutionary fact that implies that the mind cannot exist outside the cultural context. He summarises the freedom of the individual in relation to culture: "Nothing is 'culture free'; however, individuals are not merely reflections of their culture. Interaction between individuals provides a common framework for individual thoughts and enriches the lifestyle, opinions or emotions of every culture" (Bruner, 2000, p. 28).

Learning and thinking, disseminating knowledge in organised societies, take place in educational institutions. "Education is one of the most complex and at the same time most responsible human activities" (Rosić, 2009, p. 19). Therefore, it is impossible to observe educational institutions outside the cultural context, beyond correlations between culture, education and the individual, which is why Komar (2009) emphasises: "Education cannot be without a time frame, ... it cannot be out of time, ... education is essentially temporal" (Komar, 2009, p. 297).

"The basic principle of Vigotsky's work is that a child's development cannot be separated from the social context in which it occurs; learning results in development and is mediated through interaction of cultural tools and sign systems" (Eckhoff \& Urbach, 2008). 
Starting with the assumption that every culture is alive, and that in every society different cultures coexist, Lesourne (1993, p. 201) correctly raises the question: What kind of schools do we need for culture and what kind of culture do we want to disseminate in schools? In his view, any reflection on future relations between culture and schools needs to focus on the content to be found in two assumptions: (1) the role of schools is to foster a relationship with contemporary culture, (2) the contribution of schools does not lie primarily in the special programmes it proposes, but rather in creating a meaningful relationship between a certain number of different fields.

Schools can establish relationships with contemporary culture by connecting and supplementing the following three positions:

(1) The isotonic position allows the school to be sufficiently similar to the environment that surrounds it. It would be fatal for a school to act as if it were from another age; if it were to cling to obsolete values and formulas it would be considered the opposite to reality. On the contrary, school needs to be "modern" in its treatment of subjects and the pedagogical forms it applies, as well as in the behaviour it accepts and the equipment it uses (Lesourne, 1993, p. 201). Schools need to prepare pupils for life, not for schooling. Smolec (2002, p. 16) suggests: "Pupils and their teachers should get out of school ghettos, outdoors to a museum, an exhibition, to visit archaeological excavations, city streets, squares, workshops, laboratories, studios and factories, everywhere where life flourishes. They should learn there. When it is necessary to find a peaceful and pleasant environment for thinking and other mental work, let them return to their classrooms". A requirement exists for the de-intellectualisation of teaching, for prevailing over achievement-oriented aspirations deprived of content, for opening schools to life, comprehensive learning and the pupil's independence of action. Therefore, repeatedly presented old and new arguments of the critique of schools correspond to the requirement for a new quality of learning and teaching, i.e., a new school culture. Since, as Lesourne adds: “...the new society is saturated with information, overflowed with science and technology, open to the world, a society determined more by the diversity of individual situations than the volume of large societal groups, a society yearning for permanently renewing competences, shortly, a society we could also call a society of education or training" (Lesourne, 1993, p. 177). The education system is bound to gradually transform in accordance with the values of contemporary culture (Cindrić, Miljković, \& Strugar, 2010, p. 227).

(2) A distantiated, or defensive, position of the school towards culture advocates keeping it from reckless acceptance of fashionable ideas in a frantic quest for lost time and lost identity, to avoid falling into the arms of each passing seduction. 
School must not forget that its future lies in the innate, key qualities of knowledge; in other words, in its capacity to transfer knowledge effectively, to navigate knowledge reliably, to develop a capacity for cognition accurately, and to form meaning "intelligently" (Lesourne, 1993, p. 202). In this sense, Terhart (2001, p. 121) warns that today's school must take into account the influence of the "mass" media, which, with their numerical and pictorial language, simultaneously function as a complement and competition to the family and school, both expanding knowledge and providing behavioural models. The knowledge offered by such media is linked to individual events. It is, however, often an unsystematic knowledge that emphasises the extraordinary, and it is provided without historical, geographical, cultural and ethnic characteristics. It is up to the teacher to assist the pupil to position, decode and interpret such knowledge. We must bear in mind that the media open doors widely towards culture, but do not provide a platform for young people to build their own personalities.

(3) The expert opinion of schools on culture assumes that learning means: to observe the world (nature and society) and its events, to explore it, to think, reflect, conclude and act, to solve problems, to communicate with peers and everyone who learns, to express oneself orally, in writing and through art, to master cultural, work and hygiene habits, and to cope in new (unknown, unexpected) situations (Smolec, 2002, p. 43). "Nowadays, a holistic education is needed, i.e. multiple dimensions of human personality must be taken into account - physical, intellectual, aesthetic, emotional and spiritual and in such a way make a step towards an integrated individual who lives on a harmonious planet" (Terhart, 2001. p. 173). Such an approach to learning is also reflected in the basic axioms of the newer developmental psychology of learning; more precisely, in the thesis that learning is an active process that derives from contact between the individual and the environment. The confrontation of schools and cultural heritage forms the basis for developing knowledge and imagination, as well as life experience (Terhart, 2001). Nevertheless, we need to consider new media and their more extensive use by children and youth, which may take the form of a "second hand" reality, orchestrated by the media, i.e., learning that excludes the quality of gaining "hands on" life experience ("simulation" becomes better than what was once called reality). We wonder, says Terhart, "what are the possibilities for an active relation with such 'artificial cultural reality', which should become a starting point of learning for pupils?” (Terhart, 2001, p. 181). Such impoverishment in the process of gaining actual, authentic experience in school can, as Terhart states, be opposed to using an integrative approach to learning and teaching, i.e., a quality of learning that aspires to connect cognitive, social and moral learning. 


\section{Establishing a relationship between the school and the cultural-heritage environment through the concept of "action-centred teaching"}

The heritage environment includes cultural heritage that should be nurtured, preserved and transferred to children from an early age, while at the same time raising awareness of the importance of its preservation. In this sense, the task of kindergartens and primary schools is to teach, value and preserve the unique cultural and natural heritage through various teaching areas, especially creative areas - art.

The cultural-heritage environment of the school is perceived as an important resource for "lively" and dynamic upbringing activities, and education is seen as a process of internalisation of inherited historical values. In the context of heritage and traditional values, which present the entirety of the material and spiritual heritage created by humans in a certain environment, upbringing enables pupils to better understand the "present moment" and their place in it, and in so doing channels their personal development and promotes them as individuals with an identity and a developed style of behaviour, communication and reaction (Tomić Ferić, 2003).

In order to make pupils sensitive to the values of the cultural heritage in their environment, upbringing practice must provide an incentive, not in the form of the verbalisation and passive assimilation of facts, but through interactive, integrative learning, by creating conditions that enable pupils to experience and live their heritage practically, a path towards cognition through authentic activities and immediate experience that implies a creative interpretation of reality and creative communication (Stevanović, 2002). ${ }^{3}$ Such a perspective treats pupils not only as consumers of cultural values, but also as creators of culture and its future values; it approaches the school not only as a place where one is prepared for cultural living, but also as a source of culture and civilisation, as well as a promoter of a cultural and civilised way of life. A possible path towards achieving the goal of upbringing is found in Terhart's concept of integrative teaching and learning through "action-centred teaching" (Terhart, 2001). According to Terhart, the necessity of integrative learning and teaching oriented towards such learning derives from the fact that the school

3 While reflecting on heritage as a content parameter of upbringing practice, Stevanović (2002, p. 153) lists two levels of creative communication: diachronic communication, as a chronological presentation of the development of a certain heritage or as an encounter with the topic of the past through the lens of the present time; and synchronic communication, as an interdisciplinary observation, i.e., studying heritage from the perspective of heterogeneous educational areas (customs, beliefs, songs, dances). This is a multidisciplinary approach to heritage contents. 
experience protrudes more intensively in the life environment of the pupil and influences the entire personality, and thus the school increasingly becomes life itself. It is, therefore, necessary to change the character of learning and teaching in the school and provide a framework for experiences that surpass intellectual learning and encourage a more comprehensive developmental process in pupils. Starting from Gudjonson's overview of the action-centred approach as a methodical principle of teaching, Terhart (2001) offers the concept of actioncentred teaching (ACT), with the following characteristics:

(1) ACT implies that the pupil and the teacher jointly attempt to do something, to practice, to work while activating as many senses as possible: the mind, emotions, hands, legs, eyes, ears, etc. Spiritual and sensory-bodily activity should be "reunited" again. Studying and work, thought and action, school and life, cognition and the senses come closer again (Terhart, 2001, p. 185). Learning that aims to experience and understand the values of heritage, to construct personal attitudes and the entire personality of the pupil, has to establish an active relationship between the different experiences the pupil lives in his/her cultural-heritage environment. Such learning starts with an analysis of the pupil's authentic experiences, events and situations, through interaction with objects and social relations, and their "free" interpretation. The task of the teacher is to awaken and transfer interest, and to encourage pupils to perceive the interconnectedness of everything in life and their place in this totality. Content, principles, methods and actions, as a well as the entire didactic-methodical organisation of the classroom (school), should help to develop the pupil's personality (identity) as the basic goal (Matijević \& Radovanović, 2001, p. 68). Since the pupil is prepared in school for a better life, he/she should be included in trends of enrichment of life with valuable content in accordance with nature and the development of society - while respecting moral values. The integrative approach to learning advocates the pupil's learning and acting in life by changing and enhancing it, fitting into its trends, not merely as its part, but as its creator and cultivator. "It is important for the pupils to be aware that they are not merely passing guests in this world and life, but that they are trusted with a task of being reasonable and hospitable hosts in nature to all beings and existence in it" (Smolec, 2002, p. 109).

(2) Practising an approach that by teaching the teacher learns as well, permanent and transparent communication between the teacher and pupils is enabled during the entire process of learning and teaching. This kind of teamwork sheds light on the problems of learning and teaching (important starting points for the successful professional development of teachers); problems are resolved successfully, efficient communication is acquired, manners, language and 
thoughts are cultivated, listening and verbal expression is mastered, etc.

(3) ACT attempts to establish an active relationship with "reality". A "learn to live by living" approach - in order to understand the values of heritage in its environment - implies learning through dialogue and modelling. The effectiveness of dialogue lies not only in the direct transfer of knowledge and the potential for revealing various contradictions in life situations, but also in the opportunities for pupils' moral action and behaviour. The teacher's behaviour serves as a role model for pupils' decent and cultural behaviour. "In order to be successful in setting "positive models" while teaching, the teacher needs to be sincere, benevolent and reliable, therefore a legitimate, experienced, in one word, authentic professional, and the school needs to be the temple and the cradle of culture and the cultural centre of its environment" (Smolec, 2002, p. 113). (4) The model offers a lot of room for the self-organisation and self-responsibility of pupils, although initially mainly "co-organisation" and "co-responsibility". The activity plan is not determined solely by the teacher, but by the pupil as well. Life within and outside school, in the family and in the peer group, offers enough stimuli for choosing learning situations.

(5) ACT is goal directed and should determine the goals to be realised through activities. The problem lies in the fact that the teacher's teaching goals should be linked to the pupil's goals for action.

(6) Teaching pursues the possibility of creating concrete products. These products can be perceptible through the senses (a series of photographs, a theatre show, an overview of Latin words, etc.), or they can have a utilitarian and informative value. "Internal products" are also an option; for example, to influence a change in attitudes towards certain historical events, other nations and their customs, localities, behaviours, etc.

(7) Such teaching requires cooperation through the joint action of teachers, pupils and other people from the environment. Learning takes place through overall interaction, not only with the teacher, but with everyone involved in the process. In certain circumstances, the process of cooperation is equally important as the construction of a certain product. Social teaching is taken seriously: small groups and partnership in work activities are necessary social forms in action learning.

(8) ACT is a concept that has the capacity to integrate known and similar forms of teaching, such as: "discovery learning" (learning through research and construction by creating and verifying hypotheses), "principles of exemplarity" (reducing the volume of content, parts are reflections of a larger whole), "empirical teaching" (possibilities for experience are pursued, up to the point of explicit understanding of the principle: outside of school, to have "hands on" experience). The 
focus is not only on the experience itself. This remains on the level of emotions; it is important and good, but the experience is created only through reflection on and processing the event. As early as in the 19th century and the beginning of the 2oth century, the works of J. Dewey, along with the teaching of J. Piaget and L. Vygotsky, contributed to experiential, research and constructivist learning, which emphasises active and participatory learning. However, their work set foundations for what we nowadays identify as place-based learning. As Cohen states (2011), "We can define it as an approach to learning which uses local economic circumstances, specific history, culture, tradition and other relevant elements related to a certain community with an aim to create a more efficient connection between children and culture and members of the local community" (Cohen \& Milne, 2007, cf. Cohen, 2011, p. 2). ${ }^{4}$

(9) Finally, such teaching ideally attempts to "be engaged" in current social relationships, projects and problems, and to initiate useful and practical change. This can start primarily in school through the development of the pupil's interests in certain elective (extracurricular) activities (school cooperative, literary group, art group and other activities, decorating school corridors on certain holidays, volunteering in the school library, etc.) In this way, the pupils' work becomes public, and this encourages their growth and motivation.

The indisputable qualities of integrative learning should not be overlooked, especially in relation to the matters discussed in the present paper. Although action-centred teaching can demonstrate its success in very conditional and special circumstances, its challenging pedagogic morality enables a comprehensive spectrum of quality of learning and complete "live" experiences that surpass intellectual learning, as well as practical knowledge of basic human values and of acting upon them. In addition, by approaching heritage as an integrative area that encourages the pupil's integral, creative behaviour, we validate the contemporary pedagogical approach that we advocate: "the pupil is a holistic being, rich in potentials, "a unique occurrence" in continuous evolution, where the pupil of emotions and imagination does not oppose the pupil of intellect" (Rodari, 2001).

4 In Norway, as early as 1987, a Framework Plan of the Preschool Education and Upbringing and a National Curriculum for Compulsory Education were created that required kindergartens and schools to develop their own plans in which they specify the broadly define goals of child development in their local communities. This is explained in detail in: Cohen, B., \& Milne, R. (2007). Northern Lights: Building Better Childhoods in Norway, Children in Scotland, www. childreninscotland.org. UK, p. 26. 


\section{The cultural-heritage environment of school from the creative and artistic perspectives}

Visual-artistic creation presents an intriguing chapter in human history, and the area of art in particular is an interesting part of cultural heritage, or, as Crespi (2006) states, artistic production is an important part of cultural content. As a part of cultural-heritage content, artistic creation encompasses the visual experiences of generations, visible over vast periods of time. The language of artistic heritage is a dynamic connection to the participatory quality of society, a voice of beauty that, through heritage-human interaction, enables people to sense the shared facet of life: the universal voice, the voice of silence, the voice of the century. Being the timid bearer of the century, cultural heritage refers pupils to diachronic identity, it describes past centuries, touches invisible history, stirs emotions, and allows the visible to awaken imagination. In so doing, heritage lives a beautiful temporal dynamic of silence and echoes, creating meeting points on the trail of the past. Cultural heritage deserves attention observation - in order for it to remain visible to new generations.

Through children's artwork, an introduction to heritage is constituted through a complex communication process between the child, his/her creativity and heritage. In order to support the development of sensitivity towards creative and artistic work in the context of heritage, it is necessary to open pupils' eyes and encourage them to perceive cultural heritage and express themselves according to their capacities. Furthermore, it is certain that the development of an aesthetic understanding and artistic expression of heritage content is strongly dependent on the individual interests and experiences of each pupil, a fact that schools must take into account.

Within school activities, we believe that it is especially important that cultural heritage is taught through both the cognitive and social dimensions; in other words, communicating with heritage through artistic activities should be based on theoretical and empirical learning. Theoretical learning requires pupils to participate cognitively in the experience, collecting information about the objects of cultural heritage they encounter, whereas empirical learning implies that the pupil creates using various artistic techniques and materials, based on observation and experience.

The art teacher should assist pupils to interact with objects of their cultural heritage in order to raise their interest, to persuade them, to spark a desire in them to paint this heritage, to draw it, to express it graphically or depict it in three dimensions. In this sense, the teacher is a mediator between the pupil and heritage, a figure who facilitates empirical learning and secures the pupil's 
individual perspective; therefore, artistic activities should be planned with attention to children's knowledge and their understanding of the world in which they live.

Pupils should be invited to get out of the classroom in order to observe the environment, to observe what amazes them, to explore by observing, listening, touching, tasting and discussing the colours, forms, sizes, shapes, surfaces, rhythms and contrasts they perceive, learn and experience in the environment while observing forms of heritage. "Basic experience of observing and seeing in children is marked with personal attitudes toward objects and the environment the child observes. During this process experiences and emotions set forward different sensory experiences, and the real world reveals itself in the imagination of a child's world as a revelation of a simple, joyful existence" (Kelava, 2006, p. 73). Working in such a way, we will surely justify Terhart's concept of "action-centred teaching", and raise pupils' awareness of the existence of artistic and compositional elements within heritage. By drawing pupils' attention to the artistic quality of heritage, they will master the content they experience more successfully and translate it into an individual artistic voice. Raising awareness about the content of artistic language is significant for achieving aesthetic quality in pupils' works. If we truly seek to create a basis for developing a visuallyartistic culture in pupils, this awareness-raising through creative and artistic play is a necessity.

Pupils' artistic language on the topic of heritage should, therefore, be a free, open-minded experiment, or, more precisely, an expressive play with the ideas and materials offered to the pupil. Thereby, children's creative potentials will be released, and their artistic work will be a result of interaction between their thoughts and experiences, in accordance with their individual developmental capabilities (as will be shown in the examples below).

Selected examples from educational and upbringing practice in the Republic of Croatia refer to the good practice of connecting scientific and professional knowledge with cultural heritage content. ${ }^{5}$ These projects have made

5 As Curin (2012) mentions, the professional and scientific conferences entitled From Heritage to Heritage, initiated by $\mathrm{H}$. Ivon, introduced new strategies in practical work with children in the area of heritage content. As early as 2000 , numerous Croatian and foreign experts and scientists (from Greece, Slovenia, Italy, Portugal, France, Macedonia, and Bosnia and Herzegovina) who attended these conferences presented their projects in working with children to implement heritage stimulus. In 2007, the expressiveness of the artistic expression of children inspired by the heritage environment resulted in a touring exhibition entitled "Sea and Marine in the Past and Today", which was presented throughout Dalmatia (Hvar, Brač, Split, Solin, Kaštela and Korčula). Within the scientific project entitled Artistic Topics of the Eastern Adriatic: Art, Politics, Maritime Experience, organised by the Centre for Interdisciplinary Studies - Studia Mediterranea, at the Faculty of Humanities in Split, a monograph was printed with children's works: Heritage - Artistic Inspiration for Artistic Expression of Children. 
heritage an inspiration for working with children, and children have vividly expressed how they communicate with their social and cultural environment and how capable they are of being creative and constructive subjects in the environment they live in: pupils are perceived as creators in a concrete cultural and historical environment. By bringing together the heritage environment and artistic creation, the school can create an opportunity for the pupil to connect the past and the future in the best possible manner, and to perceive him/herself as an active and responsible mediator between heritage and society.

In 2007, the Faculty of Philosophy in Split commenced a research project ${ }^{6}$ called Eastern Adriatic Artistic Themes: Art, Politics, Maritime Experience, which included research on the territorial, national, artistic and cultural identities of the eastern coast of the Adriatic between the $14^{\text {th }}$ and $20^{\text {th }}$ centuries. In this project, this complex issue was studied in various ways: from so-called "high art" to children's creativity. The project included the study of various topics in the field of heritage environment in children's artistic creativity.

One of the goals of this project was to focus on the process of children's artistic creativity. Through the project, we sought answers as to how natural and cultural heritage environments affect children's understanding of the environment in which they live, and how children can express themselves creatively.

Starting with Terhart's concept of learning, we created a method of learning, through the educational project, that involved detailed investigation of certain heritage content and its creative expression.

The pupils' work on the project was accomplished in three phases: (1) first, visits to cultural and natural heritage sites, and raising awareness of the experience of heritage; (2) second, the process of artistic realisation; (3) third, collective reflection and evaluation of the children's artworks, with pupils exhibiting their artworks in the exhibition halls of museums and galleries (where their work was presented to the entire sociocultural community).

In the first phase of the project, the most important task of the teacher was to provide pupils an opportunity to acquire experience "first hand" through visits to important heritage sites, encounters with people important to the topic of study, direct observation of the environment (objects, monuments, natural scenery), and by collecting interesting items, such as books, photos, etc., that could be relevant to the topic. During this phase, the teacher aimed to encourage pupils to ask questions, express their opinions, recall what they already knew about the topic, and form associations with other current knowledge and life experience.

6 The project was realised within the framework of the Croatian Ministry of Science, under number 244-2440820-0794. 
In the second phase of the project, the pupils were encouraged to express themselves artistically and create art in an authentic heritage area (location, museum, gallery, monastery, workshops for arts and crafts, etc.). During this process, the teacher's most important task was to monitor pupils' involvement in what they were doing, and to encourage their collaboration and efforts to express themselves, but also to encourage them to ask questions regarding the choice of other art techniques and materials in order to express what they had experienced.

In the third phase - reflection on and evaluation of pupils' art creations - the pupils, with the help of their teachers, museum curators and gallery managers, organised public art exhibitions of their work in their own towns. They made their own programmes and invitations, and asked pupils from other schools to serve as art critics for the exhibition. The opportunity to display their artworks not only inspired a deeper understanding of their cultural, historic and natural environment, but also increased their awareness of their new (growing) competencies. This confirms Terhart's claim that "it is important to experience feelings and sensations, but only reflection and analysis of the experience creates an experience".

The pupils' works presented, shown in Images 1, 2, 3 and 4 (the main criteria for selection were spontaneity and expression), are a result of the project conducted with pupils in the lower grades of elementary school.

The children's works show how the school established a successful dialogue with the culture of its time through art classes topics (in the sense of respecting previously presented positions regarding establishing a relationship between the school and culture, Lesourne, 1993).

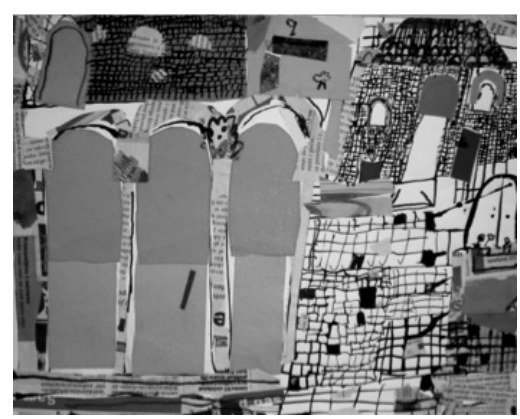

Image 1.

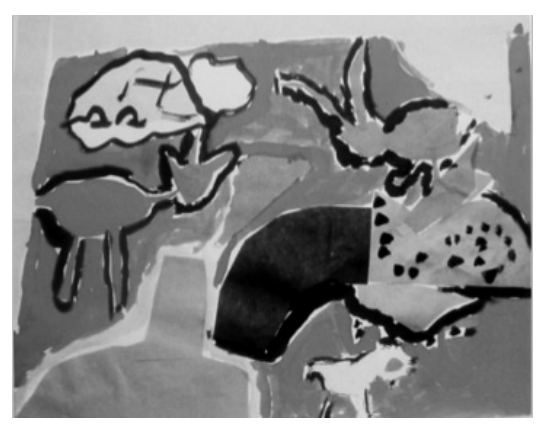

Image 2. 


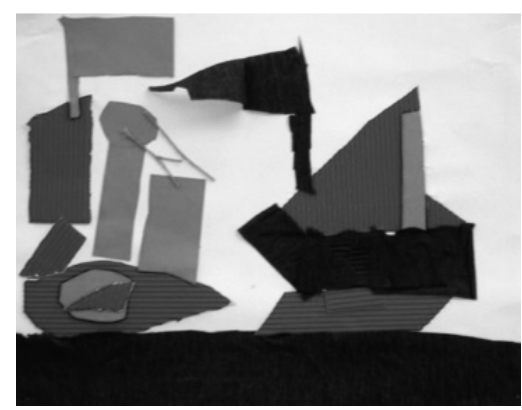

Image 3.

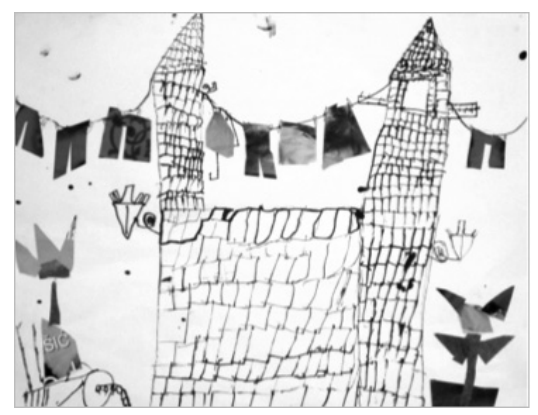

Image 4.

The artistic quality of the children's works presented originates from the fact that they have, through contact with heritage, observed heritage as creative interpreters by communicating creatively with the offered content on levels of diachronic and synchronic communication (Stevanović, 2002, p. 152). We have identified the following pedagogic positions:

(1) The artistic motives of heritage should be presented to pupils in a problematic way, because this stimulates children's curiosity and helps them to understand the reasons for learning artistic language. Learning about heritage based on one's own artistic research and discovery increases the intrinsic motivation and intellectual power of pupils, thus making their perception more efficient and their artistic expression richer and more interesting. The observation of artistic and compositional elements in heritage content becomes an act of discovery and satisfaction through an individual quest, through a joyful exploration of the heritage environment, through focused observation of artistic language with regard to the experience and to artistic expression. This is emphasised by Kvaščev (1981, pp. 255-261), who refers to research arguing that creative perception is one of the important components of the creative process, and that the child's perceptive and sensory capacities can develop rapidly in early childhood. Gardner (1999, in Pivac, 2007) also highlights this point, stating that capacities for perception are developed considerably through the arts.

(2) The emotional component and the pupils' imagination, which are fully expressed, contribute significantly to developing the holistic mental life of pupils, helping them to overcome templates and schematics in artistic works and making the spirit receptive to the birth of new ideas and the discovery of previously unrevealed aspects of heritage.

In contact with heritage content, it is necessary to change artistic motives, techniques and paper formats frequently, and it is important to encourage pupils to work in combined techniques of artistic expression, in order to support the induced motivation and creativity. In an atmosphere of mutual respect, through free 
communication, pupils freely exchange and develop artistic ideas, resulting in original artistic solutions.

(3) Creative artistic games of recomposition, redefinition and combining (appropriate to the pupils' artistic activities) create possibilities for the dynamic restructuring of existing artistic heritage content, making pupils think of new ways of connecting and structuring the available artistic and compositional elements, thus achieving their own new artistic knowledge through artistic activity. Working in this way, pupils communicate with the heritage both diachronically and synchronically, and their artistic work arises spontaneously as a result of diverse activity, which is a basis for developing many other competences. As Sekulić-Majurec (1997, p. 60) says, "creative thinking of pupils should be developed because it enhances metacognition of the individual, intellectual functioning and problem solving capacities". Artistic activities develop creative thinking, which is then transferred to external situations beyond art, resulting in the pupil's success in other areas of learning and living as well.

As long ago as 1929, A. N. Whitehead wrote: "There is only one subject important for education, and that is life in all its realisations" (cf. Anderson, 2003, p. 59). The pupils got out of the classroom during the creation of the artistic works presented, visiting places where they could witness the visual beauty of cultural heritage and observe life in its different forms. They were encouraged to recognise those parts of their environment that had, until then, remained unrecognised, because, as Husković (2009) says, plainness is the basic precondition for, and the beginning of, the aesthetic act. The artworks presented bear witness to the pupils' efforts to learn to think about life and the environment with a perception that frees them to notice artistic values, making their experiences alive and purposeful. We encounter elements of artistic language in two forms, as stated by Damjanov (1991): as sensory (visual) and sensory performance (artistic). The pupils successfully translated this experienced visual sensuousness into consciousness and knowledge about the artistic language of heritage. Matasović (2001) states: "There are different criteria for defining language, which in a certain sense originate from three basic functions of language: communicational - corresponding to the criteria of comprehensibility, cognitive - corresponding to the structural criteria and values - determined by the criteria of identification of the speaker" (Katunar, 2008, p. 82). These linguistic criteria are also facets of artistic language.? In the $21^{\text {st }}$ century, the communication structure of artistic language has been

7 The language of visual art is part of the structure of art and a mode of communication in the fine arts. The language of visual art is a wider term than visual elements (line, colour, surface, etc.) or art pattern, because it involves the meaning that it can receive, read and experience. The purpose of the language of visual art is to enable the visual reading of drawings, paintings, sculptures and architecture. 
absolutely indisputable: it is artistic language that enables the receptibility of the mutual understanding of different visual-artistic symbolic worlds. The cognitive criteria of artistic language are based on the innate human capacity for observation and visual thinking, which, once structured, becomes the basis for learning visual-artistic language, while the criteria of the values of use of artistic language lie in the individual artistic language of each artist, which determines the criteria for artist identification. We can conclude that artistic language is learned and taught in socially motivating relationships and situations: it develops and exists in artistic-aesthetic communication influenced by learning, education and the environment in the process of acquiring artistic culture, to which the artworks presented bear witness.

During the creation of the artworks, we asked the teachers to decode and interpret the knowledge of culture gained by the pupils, knowledge that enables pupils to develop their own personalities, or as Phillipson states: "Art is present in culture with a function of practical conceptualisation. It serves as a way to place art in relation towards us, and to establish our relationship with it" (Phillipson, 2002, p. 284). Sociocultural cognition perceives knowledge as a constructive process, and learning as a process by which pupils become aware of themselves in society. Given the creativity of the artistic expression, it is clear from the artworks presented that the pupils experienced heritage in a genuinely emotional way, thus helping them to understand themselves and others in the process of creating aesthetic forms. The quality of the artworks presented is reflected in the fact that pupils created their perspectives of reality guided by their own artistic experience. Through the pupils' artwork, cultural heritage has become a key for the construction of meaning in the understanding of the relationship between the pupils and society (the environment). Construction of meaning is a process of dialogue that engages people in communication, and through artworks related to cultural heritage we can provide an opportunity for pupils to construct their own cultural meanings that allow social communication to take place, while, at the same time, the pupils' personality is developed along with an awareness of belonging to their own culture. The released force of visual cognition is transformed in the pupils' artistic-creative artworks as a result of an experiential cognitive interaction with heritage, enabling the pupils to develop their cognition through artistic creation. As explained by Pivac (2007, p. 32), the most frequently used activities that can encourage children's creativity in the area of artistic expression are: directing the children's attention to a certain phenomenon or form, evoking their memory through conversation about things they have seen and experienced, encouraging their fantasy and imagination regarding a certain topic, whereby children find new solutions in 
different variations of known and acquired experiences, or by transposing different non-visual perceptions and concepts into artistic expression.

Piaget (1976, p. 20) says that "to understand means to discover or reconstruct through rediscovery. Such conditions must be met if in the future individuals will be formed capable for productivity and creativity, and not only for recognition". Pupils' artworks are an excellent depiction of Piaget's thought; they speak of the very power of creation of new flexible ideas and images through the combination or reorganisation of previous experiences, which is a serious and deeply creative capacity. During pupils' encounter with cultural heritage, they focus on action and are encouraged to notice rules of form in the artistic language of the heritage. This mode of children working through self-activation supports Piaget's thesis "of the child as the main constructor of its own selfunderstanding" (cf. Wood, 1995, p. 205). As Ingarden points out (1915), "what is important for constitution of an aesthetic experience is not the spontaneous emotional reaction to sensory qualities of an object, but a focused exploration" (cf. Spajić, 1989, p. 57). Pupils' activity, their active participation, becomes the value of the contemporary school. Therefore, "active learning becomes more and more a term of the contemporary pedagogical-methodological literature referring to the activity in which the child through his/her experience of independent exploration - with the support, cooperation and supervision of adults - acquires knowledge and capabilities in accordance with personal developmental potentials" (Kuščević, 2007, p. 22).

Vigotsky's theory, which belongs to early theories of social constructivism, is based on the premise that the social environment in which the child gains experience is significant for the development of higher cognitive functions. "As opposed to Piaget, who deems that learning is conditioned by the level of biological maturity, Vigotsky argues that social learning precedes development. The basis of cognitive development is learning a system of symbols which enable a child to reconstruct meaning of the phenomena from its surrounding". (Vizek-Vidović et al., 2003, p. 57). Therefore, it is important to bring children closer to their environment: to nature and heritage, as well as to cultural, artistic values through artistic and creative activities.

\section{Conclusion}

Contemplation of the relationship between the school and its heritagehistorical-cultural environment is purposeful for various reasons: it illustrates the effects of cultural traditions on upbringing and education; it points to the need for the preservation and renewal of cultural traditions; it helps us to 
understand ourselves and our place in the world; it points to the desirable core of common universal values that should be nurtured through upbringing and learning; and it emphasises pupil-centred development, with pupils as future promoters of authentic life, humanistic and cultural values. This consideration is irreplaceable for developing cognition that supports a deep understanding of previous events, in order to cope with the present in a better way, but also to make a better judgement of the future of "solidarity" (Nazhao, 1998).

School must value the meaning and experience that pupils acquire outside of school, and it must incorporate this into a more dynamic learning process, because, as Cohen (2011) says, the place of our upbringing, our cultural and local community, has a major significance for, and impact on, the lives, learning and development of the identity of children and youth. Education and upbringing are directed to learning in the immediate cultural-heritage community and they are a significant tool that pupils can use to learn and appreciate their own cultural heritage and identity (Cohen, 2011, p. 2). ${ }^{8}$

As a possible thematic framework and incentive for a project-based approach in schools, the cultural-heritage environment of school offers numerous possibilities for a correlation between heterogeneous - particularly artistic areas. Correlation and integration of heritage content and synchronic creative communication can be realised particularly effectively in pupils' artistic expression (language, music, dance, artistic, etc.).

After meetings of theoreticians and practitioners from Dalmatian primary schools, ${ }^{9}$ where pupils' and teachers' heritage projects entirely or partially following the concept of "action-oriented teaching" were presented, our experiences reveal a richer and more integrated knowledge of pupils in this teaching area, especially in the humanities and in artistic subjects. They also point to the fact that learning in the authentic environment is more motivating, active and "lively", as well as being cooperative and creative. ${ }^{10}$ All of this impacts school culture, not only in terms of a more dynamic organisation of learning, or of the didactic aspect or the aspect of materials, but primarily through more open relationships between teachers and pupils, as well as between pupils, school, parents and other adults from the social environment.

8 Cohen, B. (2011). Razumjeti sebe i druge: važnost mjesta odrastanja i vlastitog identiteta u multikulturalnom društvu. Dijete vrtić obitelj, br. 65. Pučko otvoreno učilište Korak po korak, pp. 2-7 from: Cohen, B., \& Milne, R. (2007). Northern Lights: Building Better Childhoods in Norway, Children in Scotland, www.childreninscotland.org. UK, p. 26.

9 Expert-scientific conferences Days of Primary Schools of the Splitsko-Dalmatinska County “Towards a Quality School” (eight such conferences have been held so far). Texts by Ivon, H. (2002, 2007), and Kuščević \& Pivac (2008) should also be taken into consideration.

10 Projects presented in the Proceedings of "The 8th Days of Primary Schools of the SplitskoDalmatinska County - Towards a Quality School”, Split: Hrvatski pedagoško-književni zbor Ogranak Split; Filozofski fakultet Sveučilišta u Splitu. 
Schools should introduce pupils to artistic cultural heritage from the earliest possible age, focusing on the creation of opportunities for children to see the artistic value of heritage as their culture. Pupils should be able to take part in school experiences involving heritage in their creative artwork within the framework of teaching art, in order for them to know how to value, recognise and understand the significance of cultural heritage in the society in which they live. Artistic activities inspired by heritage content offer pupils an opportunity for deep experience, for impressions that inspire "liveliness", spontaneous expression, the possibility of "entering" relationships, and of experimenting and exchanging their internal richness with others. A pupil who possesses a "key" for the identification and interpretation of elements and levels of experience will easily be able to transform him/herself into the "protagonist" of an artistic creation (Supek, 1987). This connection is evident in the examples given above, as well as in reported observations by the teachers in the arts field who were involved in our project.

Apart from everything mentioned thus far, a quality relationship between the school and its cultural-heritage environment through artistic projects and action-centred teaching can decrease the "prejudice" of many school staff, and of those outside school, that the arts are not sufficiently intellectually challenging future professions for pupils. Most often, art is discussed as entertainment, as a "nice" cultural experience of pupils realised to the extent that time and circumstances allow. Even those who teach art often describe their efforts as nurturing creative expression, and forget that creativity is not deprived of thought, intellectual effort and the acquisition of knowledge, making an important contribution to strengthening the culture of mind and forming the personality (Efland, 2002, pp. 6-7).

An extremely significant part of this art project was the teamwork of pupils, teachers, educators, parents and specialists in various fields of art and culture. As a result, learning about heritage and its values became a joint construction of knowledge. This not only offers opportunities to integrate heritage with different subjects, but also provides a higher level of understanding of the world that surrounds the child. The travelling children's art exhibition, which made its way through the towns and settlements of Dalmatia, and the scientific monograph entitled "Heritage - The Artistic Impetus for Artistic Expression in Children", suggest that the heritage of the area in which pupils live is not learned in classrooms but in the heritage environment. 


\section{Reference}

Anderson, T. (2003). Art education for life. International Journal of Art \& Design Education, 22(1), $58-66$.

Bruner, J. (2000). Kultura obrazovanja. Zagreb: Educa.

Bruner, J. (1990). Acts of Meaning. Cambridge, Mass.: Harvard University Press.

Cindrić, M., Miljković, D., \& Strugar, V. (2010). Didaktika i kurikulum. Zagreb: IEP-D2.

Cohen, B., \& Milne, R. (2007). Northern Lights: Building Better Childhoods in Norway, Children in

Scotland, UK, p. 26. Retrieved from www.childreninscotland.org

Cohen, B. (2011). Razumjeti sebe i druge: važnost mjesta odrastanja i vlastitog identiteta u

multikulturalnom društvu. Dijete vrtić obitelj, (65), 2-7.

Crespi, F. (2006). Sociologija kulture. Zagreb: Politička kultura nakladno-istraživački zavod.

Ćurin, S. (2012). 90. obljetnica dječjeg vrtića u Hvaru. In H. Ivon (Ed.), Zbornik radova Od baštine za baštinu 9. Dani otočnih dječjih vrtića Splitsko-dalmatinske i Dubrovačko-neretvanske županije. Hvar: Filozofski fakultet Sveučilišta u Splitu, Dječji vrtić "Vanđela Božitković”, Hvar.

Damjanov, J. (1991). Vizualni jezik i likovna umjetnost. Zagreb: Školska knjiga.

Eckhoff, A., \& Urbach, J. (2008). Understanding Imaginative Thinking During Childhood:

Sociocultural Conceptions of Creativity and Imaginative Thought. Early Childhood, 36, 179-185.

Efland, A. D. (2002). Art and Cognition. Integrating the visual arts in the curriculum. New York,

London: Teachers College, Columbia University.

Husković, F. (2009). “Umjetničke galerije i likovne sposobnosti djeteta”. In H. Ivon (Ed.), Djeca $i$

mladež u svijetu umjetnosti (pp. 131-135). Split: Filozofski fakultet, Centar za interdisciplinarne studije Studia Mediterranea, Hrvatski pedagoško-književni zbor, Ogranak Split.

Ivon, H. (2007). Baština - Univerzalni odgojitelj. In Baština umjetnički poticaj za likovno izražavanje djece (pp. 9-21). Split: Filozofski fakultet Sveučilišta u Splitu.

Ivon, H. (2002). Temeljne vrijednosti baštine u odgoju i obrazovanju. In R. Bacalja (Ed.), Živa baština - Zbornik radova (pp. 157-166). Zadar: Sveučilište u Splitu, Visoka učiteljskog škola u Zadru. Katunar, D. (2008). Istrorumunji - jezik i zajednica. Diskrepancija, 9(13), 81-94.

Kelava, M. (2006). Od poetskog doživljaja do likovno osmišljene stvaralačke igre. In E. Kišević, Majka Bajama i bura Zmijokrila (pp. 72-84). Zagreb: Golden marketing - Tehnička knjiga.

Komar, Z. (2009). Slobodno vrijeme kao vrijeme istinskog obrazovanja. Filozofska istraživanja, 29(2), 297-302.

Kuščević, D. (2007). Mediteransko baštinsko okružje poticaj likovnom izražavanju djece. In Baština umjetnički poticaj za likovno izražavanje djece (pp. 21-29). Split: Filozofski fakultet Sveučilišta u Splitu.

Kuščević, D., \& Pivac, D. (2008). Mediteran u očima djece i mladih, Šesti dani osnovne škole Splitsko-dalmatinske županije "Prema kvalitetnoj školi”, Predgovor monografiji dječjih likovnih radova. Split: Filozofski fakultet Sveučilišta u Splitu, Hrvatski pedagoško-književni zbor Ogranak Split. 
Kvaščev, R. (1981). Psihologija stvaralaštva. Beograd: Zavod za udžbenike i nastavna sredstva.

Lesourne, J. (1993). Obrazovanje i društvo. Izazovi 200o. Godine. Zagreb: Educa

Matijević, M., \& Radovanović, D. (2011). Nastava usmjerena na učenika. Zagreb: Školske novine.

Nanzhao, Z. (1998). Suodnošenje obrazovanja i kulture u svrhu gospodarskog i ljudskog razvitka: iz

azijske perspektive. In J. Delors, Učenje - Blago u nama (pp. 269-281). Zagreb: Educa.

Ogbu, J. G. (1989). Pedagoška antropologija. Zagreb: Školske novine.

Piaget, J. (1976). The Child and Reality. New York: Penguin.

Pivac, D. (2007). Prirodna i kulturna baština kao poticaj razvoja dječje kreativnosti u području

likovnog izražavanja. In Baština umjetnički poticaj za likovno izražavanje djece (pp. 21-29). Split:

Filozofski fakultet Sveučilišta u Splitu.

Phillipson, M. (2002). Baratanje tradicijom. Perspektiva estetskih praksa i njihove analize u

kulturi tehnologije i znanosti. In C. Jenks (Ed.), Vizualna kultura (pp. 283-304). Zagreb: Naklada

Jesenski i Turk.

Rodari, G. (2001). Grammatica della fantasia. Torino: Piccola Biblioteca Einaudi.

Rosić, V. (2009). Obrazovanje učitelja i odgojitelja. Metodički obzori, 4(1-2), 19-32.

Sekulić - Majurec, A. (1997). Poticanje stvaralačkog mišljenja u školi. In M. Pavlinović - Pivac

(Ed.), Škola i stvaralaštvo - Stvaralaštvo u školi (pp. 53-66) Zagreb,: OŠ Matije Gupca.

Shweder, R. A. (1991). Thinking through Cultures: Expeditions in Cultural Psychology. Cambridge,

Mass.: Harvard University Press.

Smolec, I. (2002). Praksa i filozofija učenja. Zagreb: Školske novine.

Spajić, V. (1989). Vrednovanje likovnog djela. Pristup pedagogiji umjetnosti. Zagreb: Školske novine. Stevanović, M. (2002). Modelski pristup baštini kao izvorištu odgojno - obrazovnog rada s djecom predškolske i mlađe školske dobi. In R. Bacalja, Živa baština (pp.145-155). Zadar: Visoka učiteljska škola u Zadru.

Supek, R. (1987). "Priroda ljudske kreativnosti“. In L. Kroflin, D. Nola, A. Posilović, \& R. Supek, Dijete i kreativnost (pp. 46-65). Zagreb: Globus.

Terhart, E. (2001.). Metode poučavanja i učenja; Uvod u probleme metodičke organizacije poučavanja $i$ učenja. Zagreb: Educa

Tomić-Ferić, I. (2003). Integrirani pristup izučavanju baštine u području dječjeg umjetničkog izražavanja. In H. Ivon, Zbornik radova 3. dani otočkih dječjih vrtića "Od baštine za baštinu" (pp. 98104). Hvar: Dječji vrtić "Vanđela Božitković".

Vizek Vidović, V., Rijavec, M., Vlahović - Štetić, V. \& Miljković, D. (2003). Psihologija obrazovanja. Zagreb: IEP: Vern (Udžbenici Sveučilišta u Zagrebu = Manualia Universitatis studiorum Zagrebiensis).

Wertsch, J. V. (1991). Voices of the Mind: A Sociocultural Approach to Mediated Action. Cambridge, Mass.: Harvard University Press

Wood, D. (1995). Kako djeca misle i uče. Društveni konteksti spoznajnog razvitka. Zagreb: Educa. 


\section{Biographical note}

Hicela Ivon, Ph. D., Assistant Professor, since 1996 she has been working at the Department of Pre-school Education and Pedagogy, Faculty of Philosophy, Split. She has shown a special interest in researching the examples of interactive pedagogy, interactions with a puppet in pre-school practice.Since 2000 she has been the head of a branch of the Croatian Council for Pedagogy and Literature in Split, and since 2005 she has been an instructor and a supervisor in a project called "Reading and Writing for Critical and Creative Thinking" (RWTC) by the Open Society from Zagreb. Since October, 2011 she has been a head editor of Školski vjesnik, a journal for pedagogical and educational matters.

Dubravka Kuščević got her Arts Education $\mathrm{PhD}$ from the Faculty of Pedagogy in Sarajevo, University of Sarajevo in 2012, whereby she got the degree of $\mathrm{PhD}$ in Educational Science, in Didactics of Teaching of Visual Arts and Culture in Primary Education. She currently works at the Faculty of Philosophy in Split, University of Split, where she teaches Didactics of Visual Art and Culture at the Teachers College, and Visual Arts at the Preschool College. She does research and publishes professional and scientific papers in the area of art and didactics of art expression, and has published more than thirty papers and one book (including as a co-author). 